\title{
Byelorussia collects dose
}

\section{London}

ZIANON Pazniak, chairman of Adradzennie, the Byelorussian Popular Front for Perestroika, has accused the Moscow government of artificially producing the rain that in early May 1986 deposited radioactive pollution from Chernobyl on the province of Mogilev. In a "Statement to Western Journalists", Pazniak notes that, after the accident at Chernobyl, just $5 \mathrm{~km}$ across the Byelorussian-Ukrainian frontier, the prevailing winds meant that "tonnes of radioactive materials" were deposited in southern and eastern Byelorussia. Then, he said, a few days later, when the wind changed and "the strontium-caesium clouds were moving in the direction of Moscow", rain was artificially induced over eastern Byelorussia to save the Soviet capital.

Not only was this fact concealed from the Byelorussian public and the outside world, Pazniak claims, but no steps were

\section{NUCLEAR PLANTS}

\section{Damages for residents \\ Boston}

IN A settlement marking the first time the US Department of Energy (DoE) has conceded local damage from a nuclear weapons plant, the agency has agreed to pay $\$ 73$ million in damage claims brought by 14,000 residents living near its Feed Materials Production Center in Fernald, Ohio.

The money is intended to compensate Fernald residents for emotional distress and for significant drops in property values due to their proximity to the nuclear weapons plant. A portion of the money will also be used to fund epidemiological studies of the health of people living within five miles of the plant's perimeter.

The Fernald plant, which processes uranium for the rest of the nation's nuclearweapons complex, also ranks in volume as the third largest radioactive waste dump in the United States, behind Hanford in Washington state and the Savannah River plant in South Carolina. But in certain categories, the Fernald plant's problems are worse: the US Environmental Protection Agency has declared the Fernald plant the nation's biggest emitter of uranium.

During the trial, DoE maintained repeatedly that uranium releases from the Fernald facility presented no danger to local residents.

After the settlement was announced, DoE attorney Henry A. Gill said the decision reflected only a sense of "uncertainty" about the environmental health effects of the emissions, not an acknowledgement that emissions led to physical illness.

Seth Shulman taken to protect the local population from exposure or to treat those affected.

As a result of the cloud seeding, he says, the radiation level in the south-east of the Mogilev province (between 40 and 100 curie per square $\mathrm{km}$ ) is higher than in the $30-\mathrm{km}$ zone around Chernobyl, and significantly higher than the 15 curie per square km safety level. More than 100,000 people live in the affected zone, Pazniak notes. Already, 25 per cent of the local children are suffering from thyroid insufficiencies, and the cancer rate is rising. Yet no special medical services have been provided nor has any provision been made by the state for the affected children to go to holiday camps outside the contaminated zone.

The high radiation levels in Mogilev were first revealed last February, with the publication of contamination maps in the Byelorussian press (see Nature 337, 683; 1988). In May, further maps were issued, ostensibly as guides to mushroom pickers, which showed a far greater extent of contamination. Adradzennie, Pazniak says, is concerned about the fate of the children from the Mogilev area - but the authorities do not recognize this organization and persecute its representatives.

Unlike similar 'popular fronts' in other Soviet republics, Adradzennie was not even allowed to hold its inaugural congress in its own republic, but had to meet across the frontier, in Latvia. As a result, Byelorussian ethnic activists have been virtually driven into the arms of the far more militant Balts - which, according to leaked confidential party briefing documents, was precisely what the Party authorities hoped to avoid.

Pazniak, 18 months ago an obscure archaeologist employed at the Institute of History of the Byelorussian Academy of Sciences, hit the headlines in June 1988, when he published his account of the excavation of the mass graves of Stalin's purges in Kurapaty woods, on the outskirts of Minsk. Since then, he has become the charismatic figure of the Byelorussian ethnic renaissance, a role confirmed, last month, by his election as chairman of Adradzennie. A few days after the Adradzennie inaugural meeting, a new Byelorussian Ecological Union was established, with the high-level backing of the Byelorussian Peace Committee and other Byelorussian organizations. One of the prime movers in setting up the new organization was Ms S. Rudneva, deputy head of the Department of Nature Conservation of the Council of Ministers of the USSR. But in her address to the founding meeting, she scolded the delegates for demanding action for the victims of Chernobyl. The Chernobyl disaster, she said, had nothing to do with ecology.

Vera Rich
ATMOSPHERIC SCIENCE Germans weigh plans Munich

AfTER years of rhetoric, West Germany has announced a new initiative in research on the Earth's atmosphere. The most significant step could be the launch of a satellite to determine levels of stratospheric ozone and other trace gases.

Always among the first to champion environmental causes at political gatherings such as this month's Paris summit, West Germany has, apart from a few research groups, lagged behind the United States in gathering atmospheric data on which new environmental polices could be based. Other European countries have done equally little, but none has been as vocal in its concern for the environment as West Germany, where politicians have been thinking Green for half a decade.

If built, the proposed satellite (UFS in German) would be the first European satellite devoted specifically to climate change and the environment. UFS, which would have to be launched by 1995 for maximum effectiveness, could help fill a perceived gap in the gathering of data about the ozone layer and the greenhouse effect. Most European satellites so far have been for telecommunications or weather prediction; scientific uses have mostly been limited to extraterrestrial science. France is expected in the coming months to propose a similar environment-oriented satellite.

The UFS feasibility study signals a shift in policy, with West Germany expected to urge the European Space Agency (ESA) to give climate and environmental research a higher priority. ESA support would seem to be a necessity, as costs could reach several hundred million Deutsche marks (1 DM equals $\$ 0.52$ ).

The study will be completed by the end of 1989, and an outline could then be submitted early next year to ESA. A decision must follow quickly if UFS is to be launched before the polar platform, an ESA project, set for launch in 1997 or 1998, whose tasks also include measuring ozone and other trace gases.

West Germany is expected to push for UFS at the same time as it recommends a delay of the ESA satellite ERS-2 (Earth Resources Satellite-2). There has been talk of including ozone measurement equipment on ERS-2, but this would be superfluous if the launch date is pushed back to 1997, as the West Germans are urging.

UFS would measure ozone, nitrous oxide, methane and other trace gases, and would include oceanographic instruments to assess global warming and other climatic trends. US satellites have done the bulk of these measurements so far, but one ozone detector aboard the NIMBUS-7 weather satellite has already exceeded its planned life-span and a replacement, the Upper Atmosphere Research Satellite, is not expected to be launched until 1992 .

Steven Dickman 